\title{
AZ EURÁZSIAI HÓD (Castor fiber LINNAEUS, 1758) ÉLÖHELYHASZNÁLATÁNAK VIZSGÁLATA A SZIGETKÖZBEN
}

\author{
Varju József \& Jánoska Ferenc
}

Vadgazdálkodási és Gerinces Állattani Intézet

Nyugat-magyarországi Egyetem, Erdőmérnöki Kar

H-9400 Sopron, Bajcsy-Zsilinszky Endre utca 4.

\begin{abstract}
VARJU J. \& JÁNOSKA F.: INVESTIGATION ON HABITAT USE OF EURASIAN BEAVER (Castor fiber LINNAEUS, 1758) IN SZIGETKÖZ. Hungarian Small Game Bulletin 12: 365-371. http://dx.doi.org/10.17243/mavk.2014.365

The main purpose of our research was to survey the habitat selection of the Eurasian beaver (Castor fiber) in the Szigetköz area. We appointed six sample areas along the riverbank and examined what differences can be observed in the composition of the vegetation in case of the riverbank section visited and not visited by the beaver. Comparing the diversity of the individual areas with the ratio of the trees chewed by beavers, we found a significant relationship between the presence of the beaver in the area and the diversity of the plant species $\left(\mathrm{R}^{2}=0,7833 ; \mathrm{p}<0,05\right)$.
\end{abstract}

KULCSSZAVAK: Castor fiber, élőhelyhasználat, biodiverzitás, Szigetköz, Mosoni-Duna KEYWORDS: Castor fiber, habitat use, biodiversity, Szigetköz, Moson-Danube

\section{BEVEZETÉS}

Az eurázsiai hód őshonos, általánosan elterjedt lakója volt hazánknak. Sajnos a vízrendezések és a túlzott hasznosítás miatt állománya megfogyatkozott és a 19. század végén kipusztult (BOZSÉR, 2001). Az utolsó példányt 1854 februárjában lőtték Ács községhatárában. Néhány példány jelenlétéről még történtek feljegyzések 1856-ban Pozsony mellett, 1858-ban Ácsnál és 1865-ben Zimony közelében (BREHM, 1989).

Az 1980-as években vélhetőleg ausztriai telepítésekből leúszva újra megjelent a Szigetköz területén. Távolléte alatt a Szigetköz jelentős változásokon esett át. A 19. század végén a hajózás miatt, középvízi; majd kisvízi szabályozási munkálatokba kezdtek. A munkálatok során, kőszórásokkal szükítették a medret, ezzel együtt teljesen lezárták a mellékágakat a főmedertől, a mellékágakat pedig keresztirányú zárásokkal felosztották (SZABÓ, 2002). A következő jelentős vízi beavatkozások az 1970-es évek végén kezdődő bősnagymarosi vízlépcsőrendszer építési munkálatai voltak. Ennek során 1992-ben elterelték a Dunát az 1852-1811 folyamkilométer között. Ez jelentős vízveszteséget generált a Szigetköz tekintetében (SzABÓ, 2003). Azonban nemcsak a vízrendezés terén történtek jelentős változások. A 19. században a térség flóráját láperdők, mocsárrétek és ligeterdők tarkították. A szukcesszió első társulása a dárdás nádtippanos füzláp (Calamagrostio-Salicetum cinereae) volt, amit a feltöltődő részeken mocsári páfrányos égerláp (Thelypteridi-Alnetum) váltott fel. A teljesen feltöltött szakaszon a mocsári sásos égerláp (Carici acutiformis-Alnetum) jelent meg, melyet ligeterdők váltottak fel: bokorfüzesek (Salicetum triandrae), puhafaligetek (Salicetum albae-fragilis), további szárazodással pedig keményfaligetek (Fraxino 
pannonicae-Ulmetum). Napjainkban a bokorfüzesek és puhafaligetek helyén gyorsan növő nemesnyár (Populus x. euramericana) állományok, a keményfa ligeterdők (pl. Scillo vindobonensis-Ulmetum) helyén fehér akác (Robinia pseudoacacia) vagy feketedió (Juglans nigra) ültetvények találhatók (SIMON, 1992).

Az újra megjelenő hód ebbe a jelentősen megváltozott ágrendszerbe tért vissza. Úgy tünik, hogy folyamatosan növekvő állománya jól reagált a megváltozott körülményekre. Elsősorban a part menti erdők lágylombú fafajait kedveli (Salix spp, Populus spp, stb.). Táplálékszerzése során megpróbálja a fát a vízbe dönteni, hogy hozzáférjen a koronában lévő vékonyabb kéreghez illetve ágakhoz, amelyeket a törzsről leválasztva élelemraktárába szállít. A hód táplálékigénye napi kb. 0,08 kg növényi anyag egy testsúlykilogrammra viszonyítva, vagyis egy kifejlett egyed napi adagja kb. 1,2-2 kg. (nyárasban kb. $10 \mathrm{~m}^{3} / \mathrm{család} / \mathrm{e} v$ ) (STAVROVSKY, 1997). A kidöntött törzsek száma elsősorban attól függ, hogy abból elérhető legyen számára ez a táplálékmennyiség. A hód táplálkozásával kapcsolatban sajnos szük hazai irodalom áll rendelkezésünkre. A Hanságba visszatelepített hódok (Castor fiber) élőhely- és táplálékválasztási szokásaival CzABÁN (2003), míg a Szigetközben a hód táplálékpreferenciájával PLACZER (2005) foglalkozott. SIMÓ (2008) a Rába völgyébe spontán visszatelepülő hódokat vizsgálta, míg ERDÉLYI (2009) a szigetközi hódállomány nagyságával foglalkozott. Hazánk másik jelentős hódpopulációjával rendelkező tájegységén, a Gemenc térségében DuDÁs (2000) a hód visszatelepítésével, BozSÉr (2000) a hód lágyszárú fogyasztásával foglalkozott. A Dráván élö hódállományt BAJOMI (2011) vizsgálta.

A hód élőhely-használatával és táplálkozásával kapcsolatos tanulmányok szép számban fordulnak elő a külföldi szakirodalomban. FUSTEC et al. (2001) a Loire folyó mentén (2800fkm) vizsgálta a hódok visszatelepülését 1974-1999 között, ahol azt találták, hogy a Populus spp. és a Salix spp. fajok jelenléte meghatározó volt a hód élöhely-választásában. HEIDECE \& KLENNER-FrINGES (1992) Németországban vizsgálták a hódok élőhelyhasználatát mezőgazdasági területeken és azt találták, hogy a látogatások $75 \%$-a a parttól mért 20 méteres távolságon belül volt, míg LAANETU (1995) Észtországban azt vizsgálta, hogy a hódok milyen hatással bírnak az ottani élőhelyekre. JENKINS \& BUSHER (1979) többdimenziós kontingencia táblázat segítségével elemezte a hódok táplálékválasztását.

A környező országokban - hazánkhoz hasonlóan - komoly gondokat jelent a hód tájalakító tevékenysége. A 6. nemzetközi hód szimpózium (Horvátország, Ivaniĉ-Grad 2012.) egyik fö kérdésköre is az volt, hogyan illeszthető be a jelenlegi (erösen megváltozott) erdö- és mezőgazdálkodási struktúrába az öshonos hód visszatelepülése. Vizsgálatunk célja az volt, hogy megismerjük a hód élőhely választási szokásait a Szigetközben.

\section{ANYAG ÉS MÓDSZER}

\subsection{Kutatási terület}

A vizsgált területen - nagyságából fakadóan $\left(375 \mathrm{~km}^{2}\right)$ - mintaterületeket tüztünk ki (1. ábra). Kiválasztottunk 4 olyan partszakaszt, ahol bizonyosan feltételezhettük a hód jelenlétét, és 2 olyan területet, ahol eddig még nem találtunk jelenlétére utaló rágásokat. A mintaterületet az alábbi szempont alapján jelöltük ki:

- gazdaságilag fontos kultúra legyen,

- a mintaterület könnyen megközelíthetö legyen,

- kizártuk annak lehetőségét, hogy a mintaterületet a hód egy másik folyószakaszról látogassa,

- a teljes Szigetköz területéről nyerjünk adatokat. 
A mintaterületek a part mentén húzódnak, 50 méter hosszúak, 10 méter szélesek. Kitüzésük során NOLET \& ROSELL (1998) állítását vettük alapul, miszerint: a hód leginkább a parttól számított 6 méteren belül táplálkozik.

- Mosoni-Duna 1: (továbbiakban M1), Dunakiliti és Feketeerdő települések között található, emberi zavarástól távol eső, hódok által látogatott terület. Faállomány: vastagrudas nemesnyáras (Populus x. euramericana)

- Mosoni-Duna 2: (továbbiakban M2), Máriakálnok településhez igen közel található, jellemző az emberi zavarás, hódok által nem látogatott terület. Faállomány: vékonyrudas nemesnyáras (Populus x. euramericana), törékeny füz (Salix fragilis) eleggyel.

- Mosoni-Duna 3: (továbbiakban M3), Mecsér település után található, jellemző az emberi zavarás, hódok által látogatott terület. Faállomány: vékonyrudas nemesnyáras (Populus x. euramericana), törékeny füz (Salix fragilis) eleggyel.

- Szigetközi ágrendszer 1: (továbbiakban Sz1), Dunakiliti és a Duna közötti terület egyik ágrésze, jellemző az emberi zavarás, hódok által látogatott terület. Faállomány: mandulalevelü bokorfüzes (Polygono hydropiperi-Salicetum triandrae) növénytársulás a part mentén

- Szigetközi ágrendszer 2: (továbbiakban Sz2), Cikolasziget és a Cikola kőhíd közé eső ágrész, jellemző az emberi zavarás, hódok által látogatott terület. Faállomány: vastagrudas nemesnyáras (Populus x. euramericana)

- Szigetközi ágrendszer 3: (továbbiakban Sz3), Dunaremete település közelében, a Dunaremetei hajóállomásnál lévő ágrész, jellemző az emberi zavarás, hódok által nem látogatott terület. Faállomány: vékonyrudas fehér nyáras (Populus alba), törékeny füz (Salix fragilis) eleggyel.

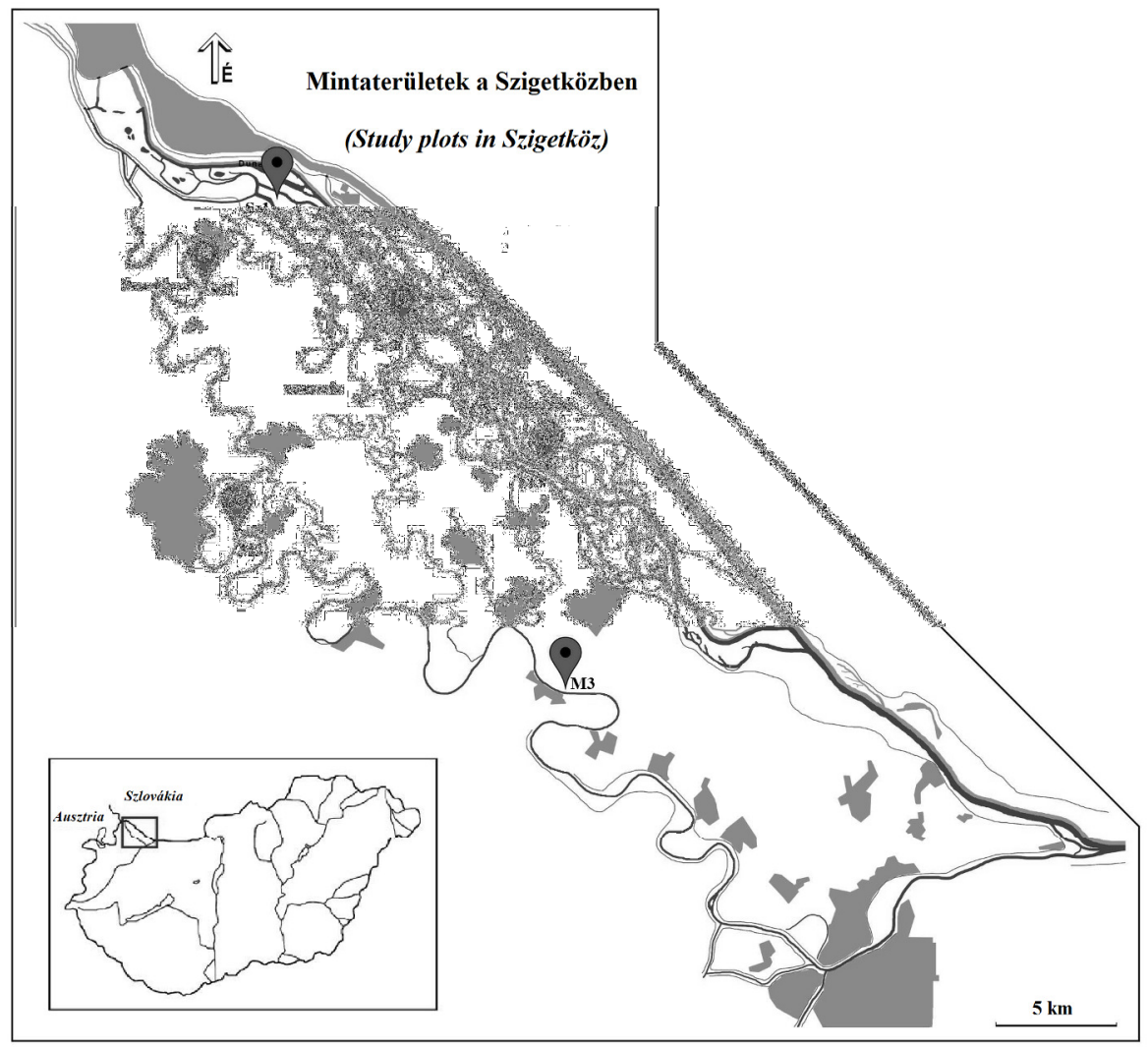

1. ábra: Mintaterületek a Szigetközben

Figure 1: Study plots in the Szigetköz area 


\subsection{Terepi adatgyüjtés}

Megvizsgáltuk, hogy a hód által látogatott és nem látogatott mintaterületeken mely növényfajok találhatóak meg nagy mennyiségben. Az állapotfelvételeket 2008 tavaszától folyamatosan végezzük. A tél kivételével minden aspektusban felkerestük a mintaterületeket és egy adatfeldolgozási munkalapon jelöltük a megtalált növények borítását (\%-ban), szociabilitásukat és fenofázisukat. A borítás alapján a növényeket Abundancia-Dominancia (továbbiakban A-D érték) értékekbe soroltuk. Az A-D érték a növényállomány alapvető mennyiségi felvételezésére alkalmas, az egyedszám (abundancia) és borítás (dominancia) együttes értékeléséből becsült viszonyszám. Ehhez a BRAUN-BLANQUET (1964) skálát használtuk (1. táblázat).

\section{1. táblázat: A-D értékek}

Table 1: A-D values

\begin{tabular}{|c|c|}
\hline A-D érték (A-D values) & Borítás (density) \% \\
\hline+ & $<1$ \\
\hline 1 & $1-5$ \\
\hline 2 & $5-25$ \\
\hline 3 & $25-50$ \\
\hline 4 & $50-75$ \\
\hline 5 & $75-100$ \\
\hline
\end{tabular}

Felvettük továbbá mintaterületeinken az ép és a megrágott fatörzsek számát is. Kapcsolatot kerestünk a diverzitás (SHANNON \& WEAVER, 1949) és a megrágott törzsek száma között.

\section{EREDMÉNYEK ÉS MEGVITATÁS}

A lágyszárú növényfajok A-D értékei alapján számolt Shannon indexeket a 2. táblázat tartalmazza.

2. táblázat: A növényzet diverzitása és a megrágott törzsek aránya mintaterületenként Table 2: Plant diversity (Shannon) and the rate of the chewed logs in the survey plots

\begin{tabular}{|c|c|c|c|c|c|c|}
\hline Mintaterület (survey plots) & M1 & M2 & M3 & Sz1 & Sz2 & Sz3 \\
\hline $\begin{array}{c}\text { Növényzet diverzitása } \\
\text { Plant diversity (Shannon) }\end{array}$ & 4,043 & 3,172 & 3,872 & 3,912 & 3,768 & 3,251 \\
\hline $\begin{array}{c}\text { Megrágott törzsek aránya (Rate } \\
\text { of the chewed logs) }\end{array}$ & 0,711 & 0,156 & 0,823 & 0,789 & 0,962 & 0,025 \\
\hline
\end{tabular}

Megvizsgálva az adatokat kitünik, hogy a hódok által nem látogatott mintaterületeken (M2, Sz3) alacsonyabb növénydiverzitást találtunk. WRIGHT (2002) tanulmányában hasonló eredményeket talált, mikor táj léptékben egy terület növényfaj gazdagságával és a kanadai hód (Castor canadensis) kapcsolatával foglalkozott. Hasonló eredményeket kapott STOHLGREN (1997), aki a Rocky Mountain Nemzeti Parkban vizsgálta a növénydiverzitást.

A mintaterületeinken felmért megrágott törzsek \%-os aránya és növényzet diverzitása közötti összefüggést (2. ábra) vizsgálva azt találtuk, hogy az alacsonyabb növénydiverzitással rendelkező mintaterületeinken alacsonyabb arányban voltak megrágva a törzsek $\left(R^{2}=0,7833\right.$ és $\mathrm{p}=0,019)$. A statisztikai vizsgálat alapján ez az összefüggés egy erős, pozitív, szignifikáns korrelációt mutat. 


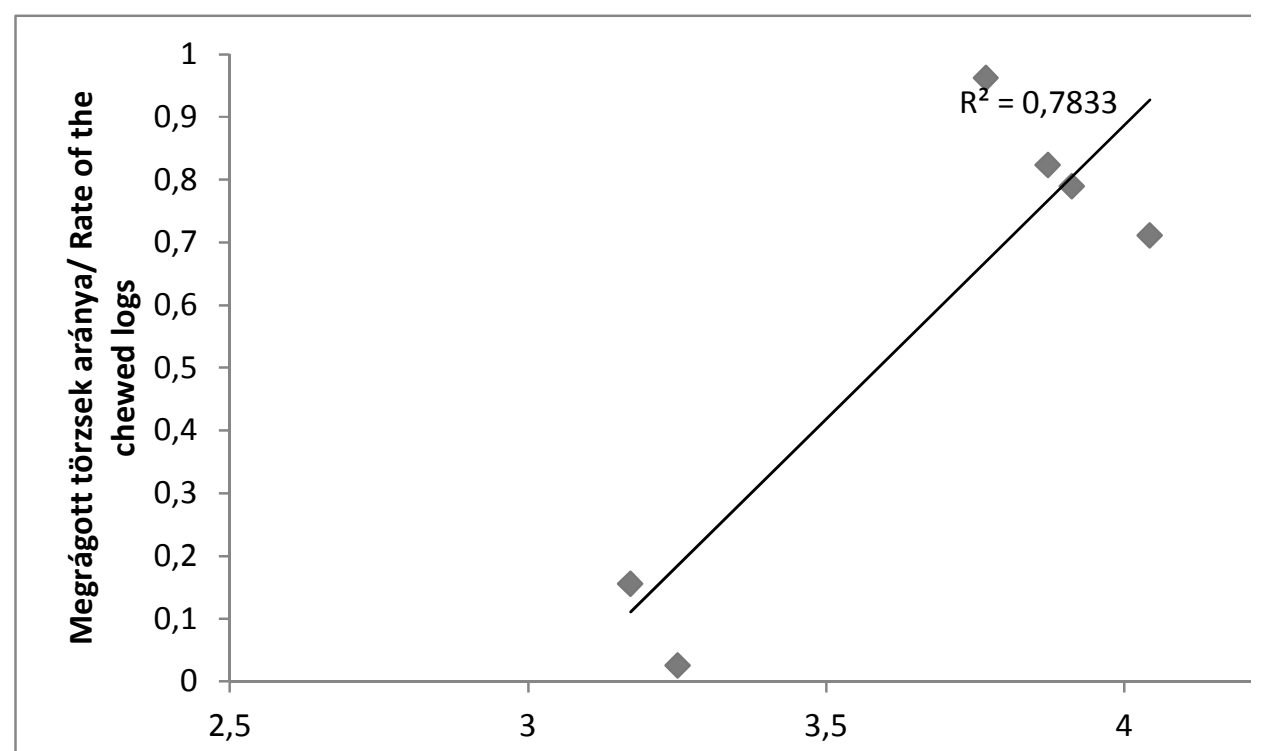

2. ábra: A növénydiverzitás és a megrágott törzsek arányának kapcsolata

Figure 2. Correlation between the plant diversity and the chewed logs rate

Ebböl arra következtethetünk, hogy a hód élőhelyválasztása során jobban kedveli azokat a partszakaszokat, ahol nagy fajgazdaságot talál. Hasonló eredménnyel zárult BALODIS (1994) vizsgálata, aki a lettországi hódközösségek élöhelyhasználatát vizsgálta és KROJEROVÁPROKEŜOVÁ et al. (2010) tanulmánya, akik hódok hullatékát (n=97) vizsgálták Csehországban.

Az eurázsiai hód (Castor fiber) táplálékszerzése során csökkenti a biológiai sokféleséget (ROSELL et al., 2005), mivel a számára legmegfelelőbb ásványi anyag tartalmú növényeket keresi (NOLET et al., 1994). Szélsőséges esetekben meg tudja változtatni a növénytársulás összetételét úgy, hogy a számára kevésbé preferált növényfajok kerülnek túlsúlyba (DONKOR \& FRYXELL, 1999), és miután túlzottan kiaknáz egy partszakaszt, továbbvándorol egy újabb területre (RosELL et al., 2005).

\section{KÖSZÖNETNYILVÁNÍTÁS}

Tisztelettel szeretnénk megköszönni DR. WINKLER DÁNIEL, DR. KOVÁCS GYULA, TARI TAMÁS, LIPPERT DÁNIEL, WEISZ JózSEF és az ÉSZAK-DUNÁNTÚLI KÖRNYEZETVÉDELMI, TERMÉSZETVÉDELMI ÉS VÍZÜGYI FELÜGYELÖSÉG segítségét.

Varju József publikációt megalapozó kutatása a TÁMOP 4.2.4.A/1-11-1-2012-0001 azonosító számú Nemzeti Kiválóság Program - Hazai hallgatói, illetve kutatói személyi támogatást biztosító rendszer kidolgozása és müködtetése országos program címü kiemelt projekt keretében zajlott. A projekt az Európai Unió támogatásával, az Európai Szociális Alap társfinanszírozásával valósul meg.

\section{IRODALOMJEGYZÉK}

BAJOMI B. (2011): Az eurázsiai hód (Castor fiber) visszatelepítésének tapasztalatai Magyarországon, Kutatási jelentés, Duna-Dráva Nemzeti Park, Budapest 
BALODIS, M. (1994): Beaver population of Latvia: history, development and management. In Proceedings of the Latvian Academy of Sciences, Section B 7-8, pp. 122-127.

BOZSÉR O. (2000): Az eurázsiai hód monitorozásának eredményei a faj gemenci visszatelepítését követően. TDK-dolgozat, Szent István Egyetem

BozsÉr O. (2001): Hódok az Óvilágban. WWF füzetek 19. 22 p.

BRAUN-BlANQUET, J. (1964): Pflanzensoziologie, Springer Verlag, Wien

BREHM, A. (1989): Az állatok világa. ÁKV Maecenas, Budapest

CZABÁN D. (2003): A Hanságba visszatelepített hódok (Castor fiber) élőhely- és táplálékválasztási szokásai. ELTE-TTK, Állatrendszertani és Ökológiai Tanszék, Szakdolgozat.

DONKOR, N.T. \& FRYXELL, J.M. (1999) Impact of beaver foraging on structure of lowland boreal forests of Algonquin Provincial Park, Ontario. Forest Ecology and Management 118: 83-92. http://dx.doi.org/10.1016/S0378-1127(98)00487-3

DuDÁs, M. (2002): Rekviem a tiszai hódokért. Vadon, 1: 36-37

ERDÉLYI N. (2009): Az eurázsiai hód (Castor fiber Linnaeus, 1758) szigetközi állományának vizsgálata. Szakdolgozat, NymE-EMK, Vadgazdálkodási és Gerinces Állattani Intézet, Sopron

Fustec, J., Lode, T., Le JACQues, D. \& CORMIER, J. (2001): Colonization, riparian habitat selection and home range size in a reintroduced population of European beavers in the Loire, Freshwater Biology 46: 1361-1371. http://dx.doi.org/10.1046/j.1365-2427.2001.00756.x

Heidece, D. \& KlenNer-Fringes, B. (1992) Studie über die Habitatnutzung des Bibers in der Kulturlandschaft. In Materialen des 2. Internationalen Symposiums Semiaquatische Säugetiere, Martin-Luther-Universität, Halle, Saale, pp. 215-265.

JENKINS, S.H. \& BUSHER. P.E. (1979): Castor canadensis. Mammalian species 120: 1-8.

Krojerová-Prokeŝová, J., BARANĈEKovÁ, M., HamŜIKovÁ, L. \& Vorel, A. (2010): Feeding habits of reintroduced Eurasian beaver: spatial and seasonal variation in the use of food resources. Journal of Zoology 281: 183-193.

http://dx.doi.org/10.1111/j.1469-7998.2010.00695.x

LAANETU, N. (1995): The status of European beaver (Castor fiber L. 1758) population in Estonia and its influence on habitats. In: Proceedings of the 3. Nordic Beaver Symposium, Finnish Game and Fisheries Research Institute, Helsinki

Nolet, B. A. \& Rosell, F. (1998): Comeback of the beaver (Castor fiber): an overview of old and new conservation problems. Biological Conservation 83(2): 165-171. http://dx.doi.org/10.1016/S0006-3207(97)00066-9

Nolet, B.A., HoeKstRA, A. \& OTTENHEIM, M.M. (1994) Selective foraging on woody species by the beaver Castor fiber, and its impact on a riparian willow forest. Biological Conservation 70: $117-128$. http://dx.doi.org/10.1016/0006-3207(94)90279-8

PlaCZER G. (2005): Az eurázsiai hód (Castor fiber L.) a Szigetközben, különös tekintettel a MosoniDunára. Szakdolgozat, NymE-EMK, Vadgazdálkodási és Gerinces Állattani Intézet, Sopron

Rosell, F., BOzsér, O., COllen, P. \& PARKER, H. (2005): Ecological impact of beavers Castor fiber and Castor canadensis and their ability to modify ecosystems. Mammal Review 35 (3-4): 248-276. http://dx.doi.org/10.1111/j.1365-2907.2005.00067.x

SHANNON, C.E. \& WeAVER, W. (1949) The Mathematical Theory of Communication. University of Illinois Press, Urbana

SiMó R. (2008): Az eurázsiai hód (Castor fiber L.) spontán visszatelepülése a Rába völgyébe. Szakdolgozat, NymE-EMK, Vadgazdálkodási és Gerinces Állattani Intézet, Sopron

SiMON T. (1992): A Szigetköz növénytársulásai és azok természetessége. Természetvédelmi Közlemények 2: 43-55.

STAVROVSKY, D. (1997): Beaver's activities influence on the environment conditions. In Proceedings of the 1. European Beaver Symposium, Bratislava

StOHLGREN, T. J. (1997): Landscape analysis of plant diversity. Landscape Ecology 12: 155-170. http://dx.doi.org/10.1023/A:1007986502230

SZABÓ M. (2002): Vízrendezések, folyószabályozások és hatásaik a Szigetközben. In: FÜLEKY GY. (szerk.): A táj változásai a Kárpát-medencében. Gödöllö, pp. 66-73 
SZABÓ M. (2003): A Duna környezetformáló szerepe a Szigetközben. In: FRISNYÁK S. \& TóTH J. (szerk.): A Dunántúl és a Kisalföld történeti földrajza, Nyíregyháza - Pécs, pp. 119-125

Wright, J., P. (2002): An Ecosystem Engineer, the Beaver, Increases Species Richness at the Landscape Scale. Oecologia 132(1): 96-101. http://dx.doi.org/10.1007/s00442-002-0929-1 